\title{
Milevica Bojović*
}

Faculty of Agronomy in Čačak

University of Kragujevac, Serbia

milevicabojovic@gmail.com

\section{DISCIPLINARY LITERACY IN ENGLISH AS A FOREIGN LANGUAGE IN BIOTECHNOLOGY ENGINEERING: READING PRACTICES AND STRATEGIES IN A HIGHER EDUCATION SETTING}

\section{Abstract}

This paper explores the concepts of disciplinary literacy and content-area literacy as well as disciplinary literacy in English as a foreign language for biotechnology engineering. Literacy practices in English as a foreign language in biotechnology are focused on the reading practices and reading strategies that students and disciplinary experts use. The participants are 94 undergraduate students of biotechnical sciences at the University of Kragujevac, Serbia, and 46 biotechnology engineering experts. The focus of the study is the use of reading strategies in English by these two groups. Based on measures of internal consistency, descriptive statistics and ANOVA, the study demonstrates that the most prominent reading strategies used by biotechnology students and experts involve re-reading for better understanding and for details, using background knowledge, using text features, and finding main ideas. The experts generally use reading strategies more frequently than the students. They are more motivated to read English-medium material than the students; they choose the text for reading on their own, confirm the purpose of reading, and discuss what is read with others significantly more frequently than the students. Reading silently is the only reading strategy where gender differences were found.

\section{Key words}

biotechnology engineering, disciplinary literacy, English as a foreign language, reading, strategies.

\footnotetext{
* Corresponding address: Milevica Bojović, University of Kragujevac, Faculty of Agronomy in Čačak, Cara Dušana 34, 32000 Čačak, Serbia.
} 


\section{Sažetak}

Cilj ovog rada je da se odrede pojmovi disciplinarne pismenosti, pismenosti $u$ okviru različitih sadržaja i disciplinarne pismenosti u oblasti engleskog kao stranog jezika u biotehnologiji. Kako je ispitivanje pismenosti na engleskom kao stranom jeziku u oblasti biotehnologije usmereno na praćenje aktivnosti čitanja i strategija čitanja, cilj rada je i ispitati koje strategije čitanja na engleskom jeziku primenjuju studenti i stručnjaci. Uzorak čini 94 studenata osnovnih studija Univerziteta u Kragujevcu i 46 stručnjaka u oblasti biotehnološkog inženjerstva. Na osnovu rezultata dobijenih statističkim postupcima kao što su interna konzistentnost, deskriptivna analiza i univarijantna analiza varijanse, istraživanje ukazuje da i studenti i stručnjaci u oblasti biotehnologije najčešće primenjuju sledeće strategije čitanja: ponovno čitanje radi boljeg razumevanja teksta, ponovno čitanje radi pronalaženja pojedinosti u tekstu, primena već stečenih znanja, korišćenje osobina teksta radi njegovog razumevanja, pronalaženje glavne ideje u tekstu. Stručnjaci primenjuju strategije čitanja češće nego što to čine studenti. Stručnjaci su i značajno više motivisani da čitaju na engleskom jeziku u odnosu na studente. Takođe, stručnjaci značajno češće samostalno biraju tekstove koje će čitati na engleskom jeziku, potvrđuju svrsishodnost čitanja datog teksta i diskutuju sa drugima o onome što su pročitali. Jedina strategija čitanja u čijoj primeni su otkrivene polne razlike jeste čitanje u sebi.

\section{Ključne reči}

biotehnološko inženjerstvo, disciplinarna pismenost, engleski jezik kao strani, čitanje, strategije.

\section{INTRODUCTION}

In order to graduate from university and fully prepare for the workforce, students need more than basic literacy skills. They need to master literacy used in academic disciplines such as science, mathematics, history, linguistics, and literature as well as various technical and engineering disciplines.

In educational contexts and at its different levels, teachers of different subject areas have employed content-area literacy strategies, an approach to reading that helps students understand information. Many teachers and researchers have gone beyond this paradigm and focused on helping students approach and understand discipline-based texts and engage in literacy skills and strategies specific to each discipline (Fang \& Coatoam, 2013). This approach is called disciplinary literacy. In order to comprehend the discipline-based texts, to grasp the purpose, main ideas, 
details in the text, and to be able to critically analyze and integrate information, readers of English as a foreign language (EFL) need to consolidate grammar knowledge, expand vocabulary, and develop and use discipline-specific reading strategies. The issue becomes even more important in the contexts of professional development in engineering as a potent field of human activities. In the contemporary world of globally interconnected engineering activities, EFL disciplinary literacy and reading skills have become vital for biotechnology engineers in performing their professional activities.

The purpose of this study is to explore the concept of disciplinary literacy and whether or how it differs from the concept of content-area literacy as well as to determine how biotechnology engineering experts and students behave when they read texts in EFL in biotechnology engineering by exploring the reading practices and strategies they use. The present study is one of the first attempts to define disciplinary literacy in biotechnology. More specifically, it aims not only to examine the perceived use of EFL reading strategies in biotechnology but also to find out potential differences between biotechnology engineering students (novices) and biotechnology experts.

\section{DISCIPLINARY LITERACY: THEORETICAL BACKGROUND}

Content-area literacy refers to a basic set of strategies for reading and responding to texts and writing with little differentiation among the content-area subjects. Content-area literacy focuses on study skills which can help students learn from subject-specific texts (Shanahan \& Shanahan, 2012: 8). In reading, the same techniques for determining important information, making inferences, asking questions, and summarizing are used in science, social studies, and mathematics. The reading strategies are the same across the subject areas; what is different is the content being read. As humans move along the continuum of literacy learning, what is learned becomes less generally useful and instruction focuses attention on more specific contents. It has been revealed that disciplines differ considerably in their fundamental purposes, specialized genres, symbolic artifacts, communication traditions, evaluation standards of quality and precision, and use of language (Shanahan \& Shanahan, 2012: 9). Considering language in use, the texts in different disciplines are structured differently, different vocabulary is used, and different grammar choices are made due to different purposes of the texts. Disciplinary literacy deals with the knowledge and abilities possessed by those who create, communicate, and use knowledge within the disciplines (Shanahan \& Shanahan, 2012: 8). It emphasizes the unique tools that the experts in a discipline use to participate in the work of that discipline (Shanahan \& Shanahan, 2008: 48) as well as the differences among the various texts used in different disciplines and the specific reading practices needed for comprehension of the concepts within each of these texts. The aim of disciplinary literacy is to identify all distinct reading and 
writing practices among the disciplines and to transform students into discipline insiders capable of approaching literacy tasks with a set of moves appropriate to the specialized demands of the discipline (Shanahan \& Shanahan, 2012:11).

Literacy is integral to the attainment of content knowledge and content is essential background knowledge for the literacy development. Foreign language literacy refers to the ability to read/write in a foreign language, which requires a broad discourse competence that involves the ability to interpret and critically evaluate a wide variety of written and spoken texts covering pragmatic and linguistic awareness, basic knowledge of lexis and grammatical structure, and cultural knowledge (Kern, 2000: 2). Disciplinary literacy in EFL for biotechnology engineering considers FL literacy, content knowledge, and reading/writing skills and strategies characteristic of biotechnology and its sub-disciplines (arable farming, fruit growing, horticulture, plant protection, animal husbandry, and food technology).

The concept of disciplinary literacy originates from three basic sources: the historical development of content-area reading, cognitive analysis of expert readers, and functional linguistics. Research on the development of content-area reading can be traced to the 1920 s when the importance of reading in content subjects was recognized. The early studies emphasized the role of vocabulary in various subject textbooks, the effectiveness of instructional procedures, and the relations of comprehension measures based on general and specific subject texts (Moore, Readence, \& Rickelman, 1983). As Moore et al. (1983: 429) concluded, different reading demands exist in different subjects either concerning different texts or different tasks. Content-area reading has a role in shaping a theoretical conception of literacy processes specific to particular disciplines, simultaneously supporting a completely different approach based on generalizable learning strategies that can be used across different subjects (Shanahan \& Shanahan, 2012). A more empirical source comes from expert reader studies in various disciplines (Shanahan, Shanahan, \& Misischia, 2011) drawing on the expert-novice paradigm from cognitive sciences, and identifying performance differences by using observations and think-aloud protocols. These studies revealed that disciplinary experts and novices differ in the way they read in their respective fields (Chi, 2006) and that disciplinary experts also differ among themselves with regard to reading (Bazerman, 1985; Peskin, 1998; Wineburg, 1991). The third source originates from functional linguistics (Halliday \& Matthiessen, 2004), which is concerned with the functions of language - what and how language does in a particular social context. The tools of functional linguistics have been used to analyze texts in technology, science, and history (Fang \& Schleppegrell, 2010; Schleppegrell, 2004; Wignell, 1994). Science texts employ technicality and nominalization to condense information about processes and phenomena while history construes actions and events through verbal and mental processes, descriptions, and background information (Schleppegrell, 2001). In history texts verbs carry much of the meaning. In biotechnology engineering, it is important to 
attain knowledge about phenomena, to invent, and to develop solutions to real problems in order to meet human needs for food. The biotechnology texts combine technical vocabulary from different fields such as botany, in which Latin and Greek words for plants and processes are used (e.g. biennial, perennial, osmosis, photosynthesis), chemistry (e.g. acidity or alkalinity of soil), zoology (e.g. beekeeping, oviposition), or food technology (e.g. caramelization, cryogenic freezing, fermentation). Disciplinary literacy draws on the concerns of content-area reading, and forms a growing body of cognitive and linguistic research that explores how disciplinary experts read and the nature of the language in disciplinary texts. Although the empirical roots of disciplinary literacy are not generally focused on teaching, the insights of these studies may be useful in the teaching context. The analyses of expert reader performances are also applicable in education contexts (Shanahan \& Shanahan, 2008). The current study provides empirical evidence of the use of foreign language reading strategies specific to biotechnology engineering and considers potential differences in reading strategy use between biotechnology experts and students (novice).

The following section concerns another important concept of this study the concept of reading strategies.

\section{READING STRATEGIES}

Reading is a highly complex process of understanding the meaning of a written text, employing various cognitive skills such as letter and word recognition, knowledge of syntax, and recognition of text types and structure (Richards \& Schmidt, 2010: 483). It is regarded as the basic academic competency and a crucial component of FL learning involving comprehension of written information, understanding the purpose of written materials, paying attention to details, and analyzing and integrating information obtained from the text (Engineering Competency Model, 2015: 11).

The term strategy refers to general approaches and specific actions/techniques used to learn a foreign language; a general approach may be that of forming hypotheses on how the foreign language works whereas a more specific strategy may refer to improvement of FL reading skills (Cohen, 1996). Language learning strategies are also referred to as learning techniques, behaviors, or actions which can lead learners to FL proficiency (Oxford \& Crookall, 1989). According to the skill area to which they relate, learning strategies may be grouped as listening, reading, speaking, and writing strategies (Cohen, 2010) while there are also theoretically-motivated and multileveled taxonomies of reading strategies (Cohen 2010; Sheorey \& Mokhtari, 2001).

FL reading strategies involve those for building reading habits (making an effort to find reading material that matches one's level or is within the zone of proximal development), developing basic reading skills (planning how to read a 
text, checking to see how much of it is understood), and determining what to do when encountering unknown words/structures (guessing the approximate meaning by using clues from the surrounding context, using a dictionary) (Cohen, 2010: 168). Many of these reading strategies are accepted in the Survey of Reading Strategies (SORS), an instrument designed to measure adolescent and adult EFL students' perceived use of reading strategies (Mokhtari \& Sheorey, 2002; Sheorey \& Mokhtari, 2001). The SORS measures three broad categories of reading strategies: metacognitive, cognitive, and support strategies. These categories, which are the subscales of SORS, are based on Metacognitive Awareness of Reading Strategy Inventory (Mokhtari \& Reichard, 2002b) and its factor analysis (Mokhtari \& Reichard, 2002a), and theoretical research. The SORS categories are as follows (Sheorey \& Mokhtari, 2001: 436):

- metacognitive strategies - intentional and carefully planned techniques used by learners to monitor and manage their own reading (e.g. having purpose in mind or using tables and figures);

- cognitive strategies - the procedures readers use while working directly on the text and handling problems that occur in understanding textual information (e.g. guessing the meaning of unknown words, re-reading the text for improved comprehension); and

- support strategies - the mechanisms intended to help the reader comprehend the text (e.g. taking notes, asking others for help to understand the text better).

Considering readers' FL strategy use, there is still a need to interpret which strategies are being used when reading. Also, those strategies which are put into one category may vary across numerous dimensions such as specificity and the extent to which they are observable (Cohen, 1996). For example, skipping an example in the text so as not to lose the train of thought may be interpreted as a metacognitive strategy (part of a conscious plan to not get distracted by detail) and also as a cognitive strategy to avoid material that would not assist in generating a gist statement (Cohen, 1996: 7). Regarding the extent to which the individual strategies are observable, some are behavioral and observable (asking questions for clarification), others are mental and behavioral but not easily observable (paraphrasing - restating ideas in readers' own words), while others are just mental (making mental translations for clarifications while reading) (Cohen, 1996: 6). Motivation is also a highly important factor in FL learning as motivated FL learners are more active in their learning activities in the classroom and the nonclassroom learning context (Gardner \& McIntyre, 1991). Consequently, more motivated FL readers are more active in FL reading activities. Furthermore, background knowledge is a key to text comprehension (Means \& Voss, 1985). Background knowledge may be described as conceptual knowledge, the knowledge about events or persons, which provides a conceptual framework for interacting 
with the world (Marr \& Gormley, 1982: 90), or as the whole of a person's knowledge including explicit and tacit knowledge, metacognitive and conceptual knowledge (Dochy \& Alexander, 1995). In reading contexts, background knowledge is the knowledge readers bring to the reading situation (Alexander, 1992).

The role of gender in FL reading has been the focus of several studies (Brantmeier, 2003; Swalander \& Taube, 2007; Young \& Oxford, 1997). It has been found that females show a more positive attitude to reading, whereas males reported significantly more goal-oriented strategies with more memorizing, elaboration, and instrumental motivation (Swalander \& Taube, 2007). Gender is also an important factor in students' perception of the use of FL reading strategies in academic settings: quantitative data have revealed that male learners think about whether the content of the text fits their reading purpose more than female learners (Akarsu \& Harputlu, 2014: 69).

The current study is based on the SORS reading strategies (Mokhtari \& Sheorey, 2002; Sheorey \& Mokhtari, 2001). The EFL reading strategies selected for examination in the current research are motivation for and purpose of EFL reading, confirming the purpose of reading, choosing autonomously which text to read, reading quickly, silent reading, using background knowledge, predicting, confirming predictions, finding main ideas in the text, using context clues for reading comprehension, taking notes while reading, re-reading the text, summarizing for better understanding, re-reading the text searching for details, using text features (tables, charts), asking others (teachers, peers, colleagues) for help when discovering the meaning of unfamiliar words in order to understand the text better, discussing what is read with others, and visualizing information read in the text.

\section{RESEARCH QUESTIONS}

The experiment was carried out to examine the perceived use of EFL reading strategies as a component of disciplinary literacy by biotechnology engineering students in an academic ESP classroom, and by biotechnology disciplinary experts during their regular professional activities. The following research questions guided the study:

1. What EFL reading strategies are used in biotechnology engineering, and how frequently?

2. Are there any differences among the biotechnology students and disciplinary experts in their perceived use of EFL reading strategies?

3. Are there any differences between females and males in their perceived use of EFL reading strategies? 


\section{METHODOLOGY}

\subsection{Participants}

A total of 140 participants took part in the research: 94 of them were biotechnology engineering students at the University of Kragujevac, Serbia, and 46 of them were biotechnology disciplinary experts employed as agricultural extension service advisors, food producers, researchers, vocational high school teachers, and university teaching staff.

The study included 63 female and 31 male students, aged between 21 and 24, in the third and fourth year of a four-year biotechnology bachelor program. All junior and senior students were exposed to compulsory academic English for Specific Purposes (ESP) courses.

Twenty-eight female and 18 male disciplinary experts, aged between 26 and 58 , experienced regular yearly programs of professional training in biotechnology engineering organized by the Serbian Institute of Application of Science in Agriculture, Serbian Ministry of Agriculture and Environmental Protection, and Ministry of Education, Science and Technological Development of the Republic of Serbia, as well as the University of Kragujevac in Čačak, Serbia.

\subsection{Variables}

The variables in the study are as follows:

a) the perceived use of EFL reading strategies in biotechnology engineering (dependent variable);

b) the level of biotechnology expertise - biotechnology engineering students and disciplinary experts (independent variable); and

c) the participants' gender - 91 females and 49 males (independent variable).

\subsection{Instruments}

Two research instruments were used in the collection of data: the Background Information Questionnaire (BIQ) and the Inventory of Reading Strategies in a Foreign Language (IRSFL) derived from the SORS, a tool for measuring adolescent and adult EFL students' perceived use of reading strategies (Mokhtari \& Sheorey, 2002; Sheorey \& Mokhtari, 2001). The BIQ was used to gather information about the participants' demographic characteristics, experiences in learning EFL, and reading habits and styles. 
The IRSFL was used to measure the perceived use of reading strategies by non-native English readers. This self-report scale consists of 20 Likert-scale items with choices ranging from "always or almost always true of me" (1) to "never or almost never true of me" (5) for 19 items. In order to make the results obtained easier to compare with other variables, the scales were reversed; the choices thus ranged from "never or almost never true of me" (1) to "always or almost always true of me" (5) for 19 of the items. The high end of the scale indicates a high frequency of use of a reading strategy while the low end indicates a low frequency of use. The exception is the item considering the purpose of EFL reading; the answer options include "for the purpose of my university studies" (1), "for my future job" (2), "for educational purposes" (3), "for searching for and gathering information by means of different media" (4), and "reading in EFL is not important to me" (5). The IRSFL instrument was adapted from the original SORS (Mokhtari \& Sheorey, 2002; Sheorey \& Mokhtari, 2001) which consists of 28 items, measuring three broad categories of reading strategies - metacognitive, cognitive, and support strategies (see Section 3 above). The items that had low rotating factor loadings (below 0.3 ) or did not seem to provide useful information were excluded from this study. An item referring to the specific purposes of reading was added. The resulting instrument (IRSFL) was reviewed by four raters (two EFL university professors, one biotechnology expert, and one psychology expert in education and experimental methodology). The items were written in the participants' mother tongue (Serbian) to avoid unnecessary miscomprehension; then they were backtranslated into English by an independent language expert for linguistic validation of the instrument. Each statement was scrutinized for clarity and appropriateness; disagreements were discussed until consensus among the raters was reached. After some revisions in wording, a pilot study was conducted among 59 undergraduate biotechnology engineering students; the instrument's overall internal reliability was established (Cronbach's alpha $\alpha=0.83$ ), indicating a reasonable degree of reliability in measuring perceived reading strategy use.

\subsection{Procedures and analyses}

The instruments used for collecting the data in the study were administered to biotechnology engineering students by their ESP teacher during their regular ESP classes - BIQ in the first week and IRSFL in the last week of the semester. The ESP classes were focused on developing the students' FL reading skills for academic and specific purposes in biotechnology engineering; they also included the development of other aspects of EFL knowledge and skills (speaking, listening, writing). The same instruments were also administered to the biotechnology disciplinary experts by their trainers (an English language trainer and biotechnology expert trainers) during their regular professional development programs - BIQ at the beginning and IRSFL at the end of their two-day training. 
The professional development programs were focused on improving the experts' professional competence including biotechnology content competence, communication competence, and ICT competence.

The measures of internal consistency, descriptive statistics, and analysis of variance (ANOVA) were analyzed using SPSS20.0 Package for Windows. For the Likert-scale strategy-use items of the IRSFL, the following key helped to interpret the means: mean values from 3.5 to 5.0 indicate high use, 2.5 to 3.49 indicate medium use, and 1.0 to 2.49 low use (Oxford, 1990).

\section{RESULTS}

The IRSFL instrument, applied to measure the perceived use of EFL reading strategies, was found to be reliable and internally consistent based on a Cronbach's alpha coefficient of $\alpha=0.85$. This result is within the scope of the coefficient values found in the literature for the SORS, which forms the basis for the IRSFL, ranging from 0.74 to 0.93 (Mokhtari \& Reichard, 2002a; Park, 2010; Sheorey \& Mokhtari, 2001).

\subsection{The use of reading strategies in biotechnology engineering}

Descriptive statistics, including a frequency analysis of overall strategy use, mean value, and standard deviation of the overall and each strategy use, were employed to describe and compare the strategies biotechnology students and experts use while reading in EFL. The means of self-reported scores for reading strategy use are shown in Table 1.

The frequency analysis revealed that almost one half of all the participants in the study (45.7\%) reported that they used EFL reading strategies frequently; also, less than a half of the respondents (45.7\%) showed medium use of reading strategies, while $8.6 \%$ of the respondents used reading strategies rarely. More than one third of the students (38.3\%) and more than one half of the experts $(60.9 \%)$ reported that they use EFL reading strategies frequently; more than a half of the students (52.1\%) and almost one third of the experts (32.6\%) showed medium use of reading strategies; finally, $9.6 \%$ of the students and $6.5 \%$ of the experts used reading strategies rarely. As for the strategy considering the purpose for reading in EFL, $11.7 \%$ of the students and $28.3 \%$ of the experts read in EFL for the purpose of their university studies; almost a quarter of the students $(23.4 \%)$ and $13 \%$ of the experts read in EFL for their future job; more than a half of the students $(55.3 \%)$ and more than a quarter of the experts (26.1\%) read in EFL for educational purposes; only $6 \%$ of the students and almost one third of the experts read in EFL in order to gather information by means of different media; and finally, reading in EFL was not important to only $3.2 \%$ of the students. 
The mean value of the overall perceived use of the reading strategies is $M$ $=3.36$ (Table 1), which indicates the participants' moderate reading strategy use.

Ten reading strategies were reported as high usage strategies. Re-reading for better understanding ("I re-read the text to increase my understanding") and re-reading for details ("I re-read to find the details when reading in English") are the two most frequently used reading strategies $(M=4.22$ and $M=4.08$, respectively). The other reading strategies at the high level of usage involve using background knowledge ("When reading a text in English, I think about what I already know on the topic") $(M=3.96)$, using text features such as pictures, tables, and graphs ("I use pictures, graphs, and charts to help me understand confusing/difficult parts") $(M=3.82)$, finding main ideas ("I look for the main idea when reading a text in English") $(M=3.76)$, asking others for help for better understanding ("I discover the meaning of unfamiliar words when reading by asking teacher/fellow student/colleague") ( $M=3.63)$, confirming the purpose of reading ("I read the text to find out if I was right about what is coming") $(M=3.59)$, using context clues ("I discover the meaning of unfamiliar words when reading by using context clues") ( $M=3.58)$, eagerness to read in English ("I am interested to read in English as a foreign language") $(M=3.58)$, reading a text silently $(M=$ 3.51). Nine reading strategies were reported as medium usage strategies $(2.5<M<$ 3.49 ), as shown in Table 1 . The least frequently used reading strategy is summarizing for better understanding ("I summarize the text to myself after I have read it"); the mean value was $M=2.48(M<2.50)$, indicating low strategy use.

\begin{tabular}{|c|c|c|c|}
\hline EFL READING STRATEGIES & $\begin{array}{c}\text { POSSIBLE } \\
\text { SCORES }\end{array}$ & $M$ & SD \\
\hline Motivation for reading in EFL & $1-5$ & $3.58^{*}$ & 1.145 \\
\hline Setting purpose for reading in EFL & $1-5$ & 2.65 & 1.003 \\
\hline Choosing autonomously what to read & $1-5$ & 3.24 & 1.279 \\
\hline Interest in reading as much as possible & $1-5$ & 3.21 & 1.160 \\
\hline Reading quickly & $1-5$ & 2.75 & 1.224 \\
\hline Reading a text silently & $1-5$ & $3.51 *$ & 1.317 \\
\hline Using background knowledge & $1-5$ & $3.96^{*}$ & 1.028 \\
\hline Predicting & $1-5$ & 3.16 & 1.158 \\
\hline Confirming predictions & $1-5$ & 3.16 & 1.158 \\
\hline Finding main ideas & $1-5$ & $3.76^{*}$ & 1.059 \\
\hline Taking notes while reading & $1-5$ & 2.58 & 1.170 \\
\hline Using context clues & $1-5$ & $3.58 *$ & .945 \\
\hline Asking others for help for better understanding & $1-5$ & $3.63^{*}$ & 1.121 \\
\hline Re-reading for better understanding & $1-5$ & $4.22 *$ & .945 \\
\hline Using text features (tables, graphs, pictures) & $1-5$ & $3.82 *$ & 1.095 \\
\hline Summarizing for better understanding & $1-5$ & 2.48 & .940 \\
\hline Discussing what is read with others & $1-5$ & 2.86 & 1.019 \\
\hline Re-reading for details & $1-5$ & 4.08* & .937 \\
\hline Visualizing information read & $1-5$ & 3.46 & 1.311 \\
\hline Confirming the purpose of reading & $1-5$ & $3.59 *$ & 1.240 \\
\hline Overall reading strategies & $1-5$ & 3.36 & 0.556 \\
\hline
\end{tabular}

Key: ${ }^{*}=$ frequent use where means $>3.50 ; M=$ mean value; $S D=$ standard deviation.

Table 1. The use of reading strategies in biotechnology $(N=140)$ 


\subsection{Differences in reading strategy use: biotechnology engineering students and disciplinary experts}

In order to determine the differences in the perceived use of reading strategies among biotechnology students and disciplinary experts, ANOVA was carried out and significant differences were determined at the 0.05 level. The results of ANOVA are presented in Table 2.

Significant differences were found in the overall perceived use of reading strategies between biotechnology students and disciplinary experts $(F=6.268, p=$ $0.013, p<0.05$ ). ANOVA revealed significant differences between the biotechnology engineering students and experts on four out of the twenty reading strategies, and these strategies are as follows: motivation for reading in EFL $(F=8.823, p=0.004$, $p<0.01)$, choosing autonomously which text to read $(F=14.907, p=0.000, p<$ $0.01)$, discussing with others about what has been read $(F=5.648, p=0.019, p<$ $0.05)$, and confirming the purpose of reading $(F=11.713, p=0.001, p<0.01)$. The disciplinary experts scored significantly higher than the students on the abovementioned strategies. There were no significant differences between the students and experts $(p>0.05)$ in using the remaining sixteen reading strategies.

Table 2 also shows that both the biotechnology students and experts frequently apply the following six strategies: using background knowledge, finding main ideas, asking other students/colleagues for help when discovering the meaning of unfamiliar words in order to understand the text better, using text features (tables, pictures, graphs), and re-reading for details $(M>3.50)$. Moreover, the strategies such as confirming the purpose of reading, motivation for EFL reading, and choosing autonomously which text to read are used not only more frequently among the disciplinary experts than among the students, but also highly frequently among the experts themselves. It is also peculiar that the experts very often read silently $(M=3.80)$ while the students use this strategy moderately $(M=$ 3.36). However, the students use context clues frequently $(M=3.63)$ compared to the moderate use of this strategy by the experts $(M=3.48)$. On the other hand, the students rarely take notes while reading $(M=2.45)$ while the experts seldom summarize the text in order to understand it better $(M=2.41)$.

\begin{tabular}{|l|c|c|c|}
\multicolumn{1}{|c|}{ EFL READING STRATEGIES } & STUDENTS & $\begin{array}{c}\text { DISCIPLINARY } \\
\text { EXPERTS }\end{array}$ & p-VALUE \\
\hline Motivation for reading in EFL & $M$ & $M$ & $p$ \\
\hline Setting purpose for reading in EFL & 3.38 & $\mathbf{3 . 9 8}^{*}$ & $.004^{* * *}$ \\
\hline Choosing autonomously what to read & 2.66 & 2.63 & $\mathbf{. 8 7 2}$ \\
\hline Interest in reading as much as possible & 2.96 & $\mathbf{3 . 8 0}^{*}$ & $.000^{* * *}$ \\
\hline Reading quickly & 3.09 & 3.46 & $\mathbf{. 0 7 5}$ \\
\hline Reading a text silently & 2.66 & 2.93 & $\mathbf{. 2 1 3}$ \\
\hline Using background knowledge & 3.36 & $\mathbf{3 . 8 0}^{*}$ & $\mathbf{. 0 6 1}$ \\
\hline Predicting & $\mathbf{3 . 8 9}$ & $\mathbf{4 . 1 1}^{*}$ & $\mathbf{. 2 4 6}$ \\
\hline Confirming predictions & 3.04 & 3.39 & $\mathbf{. 0 9 4}$ \\
\hline Finding main ideas & 3.04 & 3.39 & $\mathbf{0 9 4}$ \\
\hline
\end{tabular}




\begin{tabular}{|c|c|c|c|}
\hline Taking notes while reading & 2.45 & 2.85 & .056 \\
\hline Using context clues & $3.63^{*}$ & 3.48 & .382 \\
\hline Asking others for help for better understanding & $3.66^{*}$ & $3.57^{*}$ & .642 \\
\hline Re-reading for better understanding & $4.23 *$ & $4.20^{*}$ & .822 \\
\hline Using text features (tables, graphs, pictures) & 3.79* & 3.89* & .599 \\
\hline Summarizing for better understanding & 2.51 & 2.41 & .566 \\
\hline Discussing what is read with others & 2.72 & 3.15 & $.019^{* *}$ \\
\hline Re-reading for details & 4.09* & $4.07 *$ & .907 \\
\hline Visualizing information read & 3.47 & 3.43 & .888 \\
\hline Confirming the purpose of reading & 3.35 & 4.09* & $.001^{* * *}$ \\
\hline Overall reading strategies & 3.28 & $3.53^{*}$ & $.013^{* *}$ \\
\hline
\end{tabular}

Key: ${ }^{*}=$ frequent use where means $>3.50{ }^{* *}=$ significant difference where $p<.05 ;{ }^{* * *}=$ significant difference where $p<.01 ; M=$ mean value

Table 2. Means and differences on reading strategies between biotechnology students and experts $(N=140)$

\subsection{Gender differences in reading strategy use}

As previously mentioned, 91 females and 49 males participated in the research. According to ANOVA, significant differences were not recorded $(p>0.05)$ between females and males in their perceived use of EFL reading strategies. However, reading a text silently is the exception since the male and female participants differed significantly with regard to their perceived use of this strategy (Figure 1). The male participants practiced silent reading frequently $(M=3.82)$ while their female counterparts did it moderately $(M=3.34)(F=4.254, p=0.041, p<0.05)$.

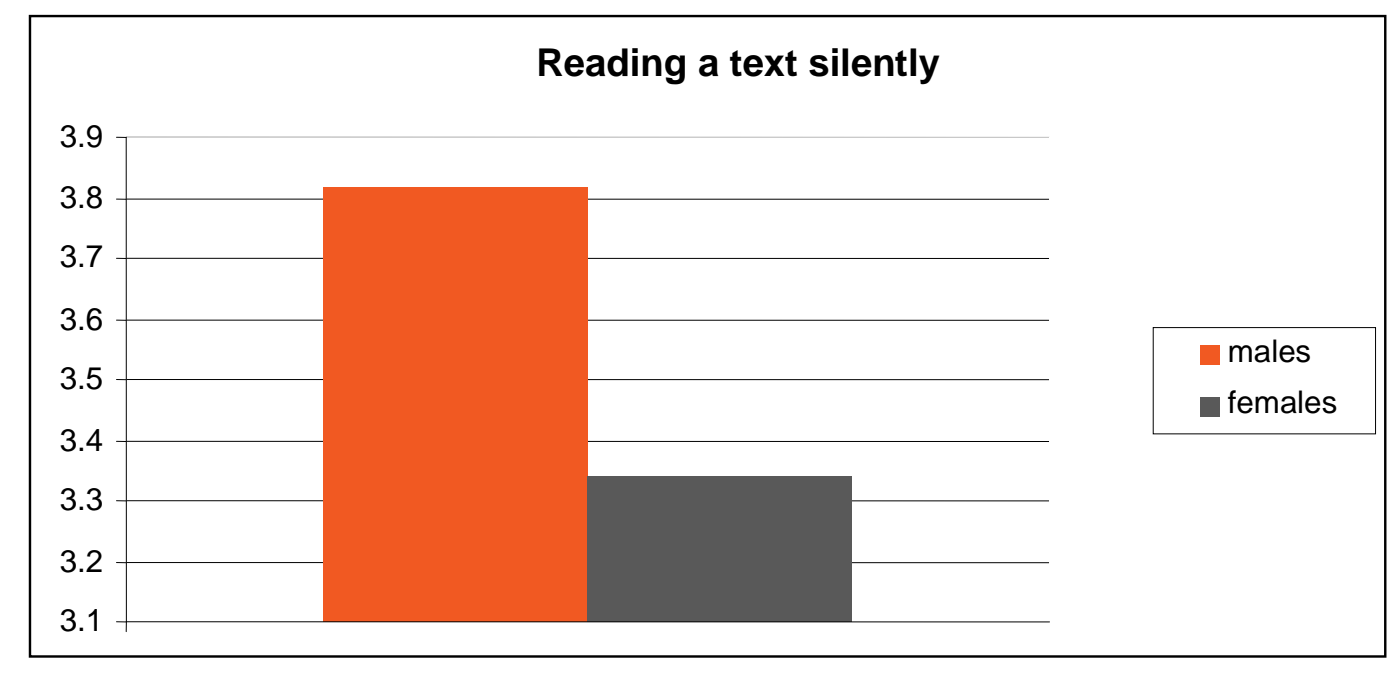

Figure 1. Gender differences in reading strategy use 


\section{DISCUSSION}

It seems that content-area reading has played a somewhat ironical role in the development of disciplinary literacy: it has pointed towards a theoretical conception of literacy processes specific to particular disciplines while practicing an approach which promotes generalized learning strategies and processes which could be adapted and used with ease across different disciplines (Shanahan \& Shanahan, 2012: 13). Basically, disciplinary differences in literacy exist due to the differences in the disciplines themselves; these differences are inherent in the various phenomena and concerns central to each particular discipline. These foundational differences necessitate differences in the text and language and, hence, differentiated approaches to reading/writing are required. Biotechnology, which is the focus of the current study, differs from other disciplines such as history, literary studies, and other fields of engineering (e.g. electrical engineering, computer engineering) because it explores the use of living systems and organisms to develop or make products or any technological application that uses biological systems, living organisms, or derivatives thereof, to make or modify products or processes for specific use in producing raw food and feed, and food processing. The texts and language in biotechnology engineering reflect the characteristics of the discipline's inherent phenomena as well as the methods and processes employed.

The findings from the IRSFL reveal that the most prominent EFL reading strategies used in biotechnology engineering involve re-reading for better understanding, using background knowledge to relate it with the text being read, using text features (pictures, tables, charts), which is in line with the findings of Park (2010) and Sheorey and Mokhtari (2001). Many studies on text comprehension indicate that successful readers call on background knowledge (Alexander, Schallert, \& Hare, 1991) to make inferences (Graesser, Singer, \& Trabasso, 1994) and to comprehend the text (Long, Winograd, \& Bridget, 1989). Background knowledge has a significant effect on student performance, explaining up to $81 \%$ of the variance in posttest scores (Dochy, Segers, \& Buehl, 1999). Rereading for details, finding main ideas, asking others for help to understand the text better or using contextual clues are also frequently used reading strategies in biotechnology engineering. The respondents are also motivated to read in English, which corroborates the finding that motivation is a significant facilitative factor in FL vocabulary and terminology learning (Gardner \& McIntyre, 1991) that remarkably contributes to FL learners' achievements (Gardner, 1985).

The reading strategies used moderately include the following ones: visualizing information read in the text (with the tendency toward frequent use), selecting the text autonomously, interest in reading as much as possible, predicting information to be read in the text, confirming prediction, discussing what is read with others (students/colleagues), speed reading, setting purpose for reading in EFL, and taking notes while reading. Moderate usage concerning visualizing information read in the text is in line with Park's (2010) findings but differs from 
Sheorey and Mokhtari (2001), who reported frequent use of the strategy. Although visualization of information is a strategy also employed in other disciplines (chemistry, physics, computer engineering), the way in which it is used in biotechnology engineering is specific to this discipline's strategy use. Visualization of information in the text being read is an important strategy for biotechnology engineers. In plant protection (a biotechnology sub-discipline), while reading a text on an economically important plant pest and relying on background knowledge of the particular pest, a biotechnology engineer visualizes the symptoms of the pest on a plant (fruit, cereals, vegetables) in order to identify these symptoms in the orchard or field and, on the basis of the identification and severity of the pest attack, decides what kinds of measures to apply - whether to treat the plants with a chemical (insecticide, fungicide) and to what extent, or not to treat it at all, or to eradicate the orchard/field in order to eliminate the pest.

The findings also reveal significant differences in EFL reading strategy use between the biotechnology students and experts. The experts generally used EFL reading strategies significantly more frequently than the students, who used them moderately. The experts were highly motivated to read in English while the students' motivation in this regard was at a moderate level. This higher level of the disciplinary experts' motivation for EFL reading may be attributed to the needs of the job itself: the experts read in order to find particular information or method to solve a particular problem. On the other hand, the students at their level of professional development are usually not capable of seeing all the benefits of reading for their future job. Also, the experts frequently selected the texts for reading whereas the students used this strategy at the medium level of frequency. The employed experts are guided by their job needs to search for the disciplinary texts purposefully and in varied ways in order to find necessary information or clues for solving problems when carrying out their professional activities; these needs may shape their reading habits and styles. On the other hand, the students are very often limited in their efforts to search for texts autonomously; it is likely that the texts and reading assignments are usually selected by their ESP course lecturers. Furthermore, the biotechnology experts very often discuss what is read with others, usually with their colleagues who are employed as experts in the field whereas the students discuss what is read at a moderate level of frequency. A possible explanation for this could be that since the experts are more experienced in the biotechnology profession, they would exchange ideas with other experts in their discipline and would apply a cooperative approach to finding solutions to potential problems; on the other hand, the students would not be so much aware of the necessity to cooperate with their peers. Finally, the experts frequently confirm the purpose of reading; even if it is not based on the results of this study, we may assume that the experts often know why they read a particular text and whether they have found what they were looking for since they have very concrete issues to solve. The students are not always aware of their future job needs. Their lack of experience may limit them in anticipating potential problems and possible 
solutions as well as the strategies to find the solutions, which can include deducing necessary information or drawing conclusions from the text related to the biotechnology discipline. The experts can detect and see features that students or novices cannot (Chi, 2006). It could be expected that experts spend a great deal of time dealing with problems at a deeper level by analyzing them qualitatively, developing a problem presentation by adding many discipline-specific and general constraints; they possess more accurate self-monitoring skills in terms of their ability to detect errors and the status of their own comprehension. The experts are more capable of choosing a more adequate strategy or procedure for a particular situation compared with novices (Chi, 2006); they are more likely than novices to use strategies that have proved to be effective (Lemaire \& Siegler, 1995). They can also retrieve relevant domain knowledge and strategies with minimal cognitive effort (Alexander, 2003). It is also interesting to note that the biotechnology students rarely take notes while reading. On the other hand, the biotechnology experts rarely summarize the text in order to understand it better; this finding is in line with the finding of Chi's expert-novice research (2006), according to which experts perceive large, meaningful patterns in given information and have superior short-term and long-term memory. In the expert-novice studies in literary, historical, and science reading/writing, the following differences were recorded: in literary reading, novices lack disciplinary-specific interpretative strategies that the experts use to make coherent interpretations (Peskin, 1998); expert historians are engaged in the processes of acquiring information, sourcing, contextualization, and corroboration while the novices read the documents making no connections to the others (Wineburg, 1991); in science reading, the purpose for reading, background knowledge (Bazerman, 1985), and sourcing (Wineburg, 1991) are the factors that determine how the experts approach the text. In this study, using background knowledge is the strategy used frequently by both students (novices) and experts; with regard to the purpose for reading in EFL, there is also no difference between students (novices) and experts since both groups read in EFL most frequently for educational purposes.

Although the biotechnology engineers in this study were found to engage in similar strategies to historians, chemists, and mathematicians (Shanahan et al., 2011), for example, using text features, contextualization, background knowledge, and paying attention to visual or graphical information, they may use these strategies differently. For example, historians treat graphics in the text as subordinate to the arguments in the text; chemists, on the other hand, consider graphics to be as important as prose, and read this repeatedly in order to transform information since they recognize that this information may provide deeper insights into the phenomenon under study; for mathematicians, formulas and prose are equally important but their reading seems to be less recursive than that of the chemists (Shanahan et al., 2011: 417-419). Biotechnology engineers use the text features (graphics, tables, charts) frequently in order to identify the problem, transform it into a sort of the solution to be applied in the orchard/field 
or in the food processing unit. Tables and graphs are critical forms of communication for engineers who need to read and process a wide range of data and use them to solve problems (Wickert \& Lewis, 2011: 115). Further research is needed into the reading strategies of experts in different disciplines and how these may differ when engaging in the unique features of disciplinary texts.

Another important finding of this study is that the biotechnology students did not use any EFL reading strategy significantly more frequently than the biotechnology experts. It is possible that the finding is a consequence of the research instrument employed. Further research may focus on the potential influence of expertise level or reading styles on using reading strategies.

Finally, the participants' gender had no significant effect on EFL reading strategy use. Generally, no differences were found between females and males in their perceived use of the EFL reading strategies, which is consistent with the results of earlier studies (Lien, 2014; Sheorey \& Mokhtari, 2001). The only reading strategy where a gender difference was noted is silent reading: male participants read a text silently more frequently than their female counterparts. This finding is not in line with other studies that reported significant variations in terms of the frequency and adaptability of reading strategies between the genders (Sheorey, 1999; Young \& Oxford, 1997). Given the disagreement with existing studies, there is a need to further explore the impact of gender on reading strategy use.

\section{CONCLUSION}

The study reported in this article is one step towards a better understanding of disciplinary literacy in biotechnology engineering. Disciplinary literacy in biotechnology engineering may be defined as the confluence of content knowledge of various fundamental sciences (biology, chemistry, physics, mathematics) applied in the production and protection of plants and animals as well as the processing of food with the skills of reading, writing, listening, speaking, critical thinking, and appropriate performance in biotechnology engineering.

This study, as one of the first attempts to define disciplinary literacy in biotechnology engineering, focuses on the specific performance in relation to reading skills and the use of particular reading strategies in the field. It reveals that biotechnology engineering students and experts use reading strategies (moderately and frequently, respectively) while reading the texts in English. The experts generally use reading strategies more frequently than the students. As for pedagogical implications, few biotechnology engineering faculty teaching staff members in Serbia receive any formal pedagogical training to teach disciplinary reading - most learn how to read for their discipline from their own supervisors/mentors during graduate training and, most often, through their own experience. At present, in the context of the Serbian education system, disciplinary reading pedagogy is housed outside of biotechnology engineering education; it is 
not uncommon for students to secure the expertise needed to accompany their understanding of disciplinary texts through their FL classes in an academic setting. Thus, FL teachers (EFL teachers in particular) become responsible for disciplinary reading pedagogy in biotechnology engineering. Since EFL teachers do not acquire knowledge of the discipline content during their formal teacher education, their EFL teaching practices involve interdisciplinary cooperation with the biotechnology experts so that the EFL teachers could grasp the knowledge and procedures characteristic of biotechnology engineering profession. Thus, simultaneously, EFL teachers offer language knowledge interwoven with biotechnology disciplinary reading expertise to their students.

This study has several major limitations that could be addressed in further research. The results of the study were based on the use of EFL reading strategies by a limited number of students and experts in a very complex and specific engineering domain. Thus these results cannot be generalized to the whole student and expert population (given the diversity among the experts employed in different sectors of the profession) in biotechnology engineering and particularly not to engineering profession in general. Moreover, the IRSFL instrument used in the research is a self-reporting tool - it means that the participants' responses depend on their sincerity and willingness to cooperate in the research as well as on their awareness of the reading strategies they use. Certain problems may arise when using Likert-scale items: participants may avoid extreme response categories and tend to take the neutral opinion (Brown, 2000), or they may tend to portray themselves in a more sociably favorable light rather than being honest (Bertram, n.d.). As the sample size and distribution are more important than the level of measurement in determining whether it is appropriate to use parametric statistics (Knapp, 1990), Likert scales are commonly used to measure latent constructs - attitudes, opinions, feelings on any language-related topics (Brown, 2000). How readers read in a foreign language depends on many factors, including participants' first language literacy and foreign language proficiency (Bernhardt \& Kamil, 1995; Lee \& Shallert, 1997), their levels of domain knowledge, purposes for reading, the characteristics of the text, and whether there was one text or multiple texts that had to be interpreted together (Hynd-Shanahan, 2008 as cited in Shanahan et al., 2011: 424). The present study is thus an initial step in validating the usage of characteristic EFL reading strategies in biotechnology engineering both by the students and the experts.

As the IRSFL instrument in the study is largely a measure of the use of EFL reading strategies rather than discipline-specific reading strategies, future research should explore the ways certain reading strategies are used in biotechnology engineering both by the students in higher education setting and by the experts in their actual reading processes to generate an instrument that can measure disciplinary-specific reading strategies. To overcome limitations of the Likert-type instrument, the perceived use of reading strategies could be subjected to more qualitative investigations employing interviews, diaries, or think-aloud 
protocols. Further studies could also investigate how the examined strategies correlate with the students' and experts' levels of reading comprehension or their reading habits and styles, particularly when reading a printed text and when reading online. Further studies could also investigate gender variations in using EFL reading strategies across populations and disciplines. This last pursuit on the further studies list is important because if gender disparities are found, they may lead teachers and researchers to seek ways to minimize them and to afford both genders maximum opportunities to achieve high levels of disciplinary literacy.

[Paper submitted 30 May 2017]

[Revised version received 20 Sep 2017]

[Revised version accepted for publication 5 Oct 2017]

\section{References}

Akarsu, O., \& Harputlu, L. (2014). Perceptions of EFL students toward academic reading. Reading Matrix, 14(1), 61-75.

Alexander, P. A. (1992). Domain knowledge: Evolving issues and emerging concerns. Educational Psychologist, 27(1), 33-51.

Alexander, P. A. (2003). Can we get there from here? Educational Researcher, 32(8), 3-4. doi:10.3102/0013189X032008003

Alexander, P. A., Schallert, D. L., \& Hare, V. C. (1991). Coming to terms: How researchers in learning and literacy talk about knowledge. Review of Educational Research, 61(3), 315-343.

Bazerman, C. (1985). Physicists reading physics: Schema-laden purposes and purposeladen schema. Written Communication, 2(1), 3-23.

Bernhardt, E. B., \& Kamil, M. L. (1995). Interpreting relationships between L1 and L2 reading: Consolidating the linguistic threshold and the linguistic interdependence hypotheses. Applied Linguistics, 16, 15-34. doi: 10.1093/applin/16.1.15

Bertram, D. (n.d.). Likert scales. CPSC 681 - Topic report. Retrieved from http://poincare.matf.bg.ac.rs/ kristina/topic-dane-likert.pdf

Brantmeier, C. (2003). Does gender make a difference? Passage content and comprehension in second language reading. Reading in a Foreign Language, 15(1), 1-27.

Brown, J. D. (2000). What issues affect Likert-scale questionnaire formats? Shiken: JALT Testing and Evaluation SIG Newsletter, 4(1), 27-33. Retrieved from http://hosted.jalt.org/test/PDF/Brown7.pdf

Chi, M. T. H. (2006). Two approaches to the study of experts' characteristics. In K. A. Ericsson, N. Charness, P. J. Feltovich, \& R. R. Hoffman (Eds.), The Cambridge handbook of expertise and expert performance (pp. 21-30). Cambridge: Cambridge University Press.

Cohen, A. D. (1996). Second language learning and use strategies: Clarifying the issues. (CARLA Working Paper\#3). Minneapolis, USA: University of Minnesota, Center for Advanced Research on Language Acquisition. Retrieved from http://carla.umn.edu/resources/working-

papers/documents/SecondLanguageLearningUseStrategies.pdf 
Cohen, A. D. (2010). Focus on the language learner: Style, strategies, and motivation. In N. Schmidt (Ed.), An introduction to applied linguistics (2nd ed.) (pp. 161-178). London: Hodder Education.

Dochy, F. J. R. C., \& Alexander, P. A. (1995). Mapping prior knowledge: A framework for discussion among researchers. European Journal of Psychology of Education, 10(3), 225-242. doi: 10.1007/BF03172918

Dochy, F., Segers, M., \& Buehl, M. M. (1999). The relation between assessment practices and outcomes of studies: The case of research on prior knowledge. Review of Educational Research, 69(2), 145-186.

Engineering Competency Model (2015). Retrieved from http://www.aaes.org/sites/ default/files/Engineering\%20Competency\%20Model_Final_May2015.pdf

Fang, Z., \& Coatoam, S. (2013). Disciplinary literacy: What you want to know about it. Journal of Adolescent \& Adult Literacy, 56(8), 627-632. doi: 10.1002/JAAL.190

Fang, Z., \& Schleppegrell, M. J. (2010). Disciplinary literacies across content areas: Supporting secondary reading through functional language analysis. Journal of Adolescent and Adult Literacy, 53(7), 587-597. doi: 10.1598/JA AL.53.7.6

Gardner, R. C. (1985). Social psychology and second language learning: The role of attitudes and motivation. London: Edward Arnold Publishers.

Gardner, R. C., \& McIntyre, P. D. (1991). An instrumental motivation in language study: Who says it isn't effective? Studies in Second Language Acquisition, 13(1), 57-72. https://doi.org/10.1017/S0272263100009724

Graesser, A. C., Singer, M., \& Trabasso, T. (1994). Constructing inferences during narrative text comprehension. Psychological Review, 101, 371-395.

Halliday, M. A. K., \& Matthiessen, C. (2004). An introduction to functional grammar (3rd ed.). London: Hodder Education.

Kern, R. (2000). Literacy and language teaching. Oxford: Oxford University Press.

Knapp, T. R. (1990). Treating ordinal scales as interval scales. Nurs Res, 39, 121-123.

Lee, J. W., \& Shallert, D. L. (1997). The relative contribution of L2 language proficiency and L1 reading ability to $\mathrm{L} 2$ reading performance: A test of the threshold hypothesis in an EFL context. TESOL Quarterly, 31(4), 713-739.

Lemaire, P., \& Siegler, R. S. (1995). Four aspects of strategic change: Contributions to children's learning of multiplication. Journal of Experimental Psychology: General, 124, 83-97.

Lien, H. Y. (2014). Reading strategy awareness of English major students. International Journal of Social, Behavioral, Educational, Economic, Business and Industrial Engineering, 8(8), 25262530. Retrieved from http://waset.org/publications/9999055/reading-strategyawareness-of-english-major-students

Long, S. A., Winograd, P. N., \& Bridget, C. A. (1989). The effects of reader and text characteristics on imagery reported during and after reading. Reading Research Quarterly, 24(3), 353-372.

Marr, M. B., \& Gormley, K. (1982). Children's recall of familiar and unfamiliar text. Reading Research Quarterly, 18, 89-104.

Means, M. L., \& Voss, J. F. (1985). Star wars: A developmental study of expert and novice knowledge structures. Journal of Memory and Language, 24(6), 746-757. https://doi.org/10.1016/0749-596X(85)90057-9 
Mokhtari, K., \& Reichard, C. A. (2002a). Assessing students' metacognitive awareness of reading strategies. Journal of Education Psychology, 94(2), 249-259. doi: $10.1037 / / 0022-0663.94 .2 .249$

Mokhtari, K., \& Reichard, C. A. (2002b). Metacognitive awareness of reading strategy inventory (MARSI), Version 1.0. Retrieved from

http://www.nwfsc.edu/Academics/AcademicSupport/ReadingtoLearn/R2L_files/2 0122_PRINT_MARSI_2002.pdf

Mokhtari, K., \& Sheorey, R. (2002). Measuring ESL students' awareness of reading strategies. Journal of Developmental Education, 25(3), 2-10.

Moore, D. W., Readence, J. E., \& Rickelman, R. J. (1983). An historical exploration of content area reading instruction. Reading Research Quarterly, 18(4), 419-438. doi:10.2307/747377

Oxford, R. L. (1990). Language learning strategies: What every teacher should know. New York: Newbury House.

Oxford, R. L., \& Crookall, D. (1989). Research on language learning strategies: Methods, findings, and instructional issues. The Modern Language Journal, 73(4), 404-419. doi:10.1111/j.1540-4781.1989.tb05321.x

Park, Y. H. (2010). Korean EFL college students' reading strategy use to comprehend authentic expository/technical texts in English. (Unpublished doctoral dissertation). Department of Curriculum and Teaching, University of Kansas, USA. Retrieved from https://kuscholarworks.ku.edu/bitstream/handle/1808/6639/Park_ku_0099D_10 804_DATA_1.pdf?sequence $=1$

Peskin, J. (1998). Constructing meaning when reading poetry: An expert-novice study. Cognition and Instruction, 16(3), 235-263.

Richards, J. C., \& Schmidt, R. (2010). Longman dictionary of language teaching and applied linguistics (4th ed.). Harlow: Pearson Education Limited.

Schleppegrell, M. J. (2001). Linguistic features of the language of schooling. Linguistics and Education, 12(4), 431-459. doi: 10.1016/S0898-5898(01)00073-0

Schleppegrell, M. J. (2004). The language of schooling: A functional linguistics perspective. Mahwah, NJ: Lawrence Erlbaum Associates.

Shanahan, T., \& Shanahan, C. (2008). Teaching disciplinary literacy to adolescents: Rethinking content-area literacy. Harvard Educational Review, 78(1), 40-59.

Shanahan, T., \& Shanahan, C. (2012). What is disciplinary literacy and why does it matter? Topics in Language Disorders, 32(1), 7-18. doi: 10.1097/TLD.0b013e318244557a

Shanahan, C., Shanahan, T., \& Misischia, C. (2011). Analysis of expert readers in three disciplines: History, mathematics, and chemistry. Journal of Literary Research, 43(4), 393-429. doi: 10.1177/1086296X11424071

Sheorey, R. (1999). An examination of language learning strategy use in the setting of an indigenized variety of English. System, 27(2), 173-190. doi: 10.1016/S0346251X(99)00015-9

Sheorey, R., \& Mokhtari, K. (2001). Differences in metacognitive awareness of reading strategies among native and non-native readers. System, 29(4), 431-449. doi: 10.1016/S0346-251X(01)00039-2

Swalander, L., \& Taube, K. (2007). Influences of family based prerequisites, reading attitude, and self-regulation on reading ability. Contemporary Educational Psychology, 32(2), 206-230. doi:10.1016/j.cedpsych.2006.01.002 
Wickert, J., \& Lewis, K. E. (2011). Introduction to mechanical engineering (3rd ed.). Stamford, USA: Cengage Learning.

Wignell, P. (1994). Genre across the curriculum. Linguistics and Education, 6(4), 355-372. doi: 10.1016/0898-5898(94)90003-5

Wineburg, S. S. (1991). On the reading of historical texts: Notes on the breach between school and academy. American Educational Research Journal, 28(3), 495-519.

Young, D. J., \& Oxford, R. (1997). A gender-related analysis of strategies used to process written input in the native language and a foreign language. Applied Language Learning, 8, 43-73.

MILEVICA BOJOVIĆ is an EFL teacher at the University of Kragujevac, Faculty of Agronomy in Čačak, Serbia. She obtained her $\mathrm{PhD}$ degree with the study of developing the communicative language ability in English of biotechnology engineers, exploring affective factors, metacognition, and students' self-evaluation. Her fields of research include ESP teaching, applied linguistics, second language acquisition, e-learning/teaching, teacher education, and adult education. She is a member of the European Society for the Study of English and International Literacy Association. She has published in national and international journals. 